\title{
High School Dropout of Mexican Origin and White Non-Hispanic Youths in United States
}

\author{
Alejandro Francisco Román ${ }^{1}$ \\ ${ }^{1}$ Universidad Autónoma De Nuevo León, Mexico \\ Correspondence: Alejandro Francisco Román, Universidad Autónoma De Nuevo León, Mexico.
}

Received: November 12, 2014

Accepted: December 3, 2014

Available online: December 24, 2014

doi:10.11114/ijsss.v3i1.582

URL: http://dx.doi.org/10.11114/ijsss.v3i1.582

\begin{abstract}
The aim of this paper is to analyze the factors and reasons causing high school dropout of a cohort of Mexican and white non-Hispanic students. The source of data used is the National Education Longitudinal Survey (NELS 88-92), which is representative at national level. The main findings are: student's age, labor force participation, school absence, extracurricular activities, socioeconomic strata, parent's education, family structure, number of siblings and type of school are influencing high school dropout for Mexican origin and White non-Hispanic youths. With respect to reasons for high school dropout, we found they are related with early adulthood. For Mexican origin young people, the first child or pregnancy is the main reason for school dropout, while white non-Hispanic is labor force entry.
\end{abstract}

Keywords: Mexican origin youths, White non-Hispanic youths and school dropout.

\section{Introduction}

In most of the studies about education of Mexican origin youth in the United States, authors coincide in one concern: Hispanic students, in general, and Mexican or Mexican origin students in particular, do not do well in United States schools (Tinley, 2003; Levine, 2001). This assertion implies low school stages; it means also high levels of disapproval, high dropout rates during high school and low transition percentages to higher education. In short, in the researches it is recognized ethnic group facing more serious problems at American schools are Mexican origin youths (Levine, 2001; Rumbaut \& Portes, 2001; Tinley, 2003).

Mexican origin youths, compared with other immigrant groups have high school dropout rates and low grades during high school. This is due, according to some researches, to gender, to labor market participation, recent arrival to hostess country, to come from a low socio-economical class, to come from a one-parent family, lack of familial support system, difficulties in adaptation process and poor academic preparation that most of the immigrants had at their places of origin (Schmid, 2001; Giorguli, White \& Glick, 2003).

Most of the studies refer to determinants of educational status of Hispanics and White non-Hispanic, but there exist few researches that deal with incidence of diverse factors about Mexican origin young people school dropout, and much less those distinguished by the time each generation arrived (Portes, 2008; Telles \& Ortiz, 2011). This last point is relevant since according to diverse studies (Neidert \& Farley, 1985; Telles \& Ortiz, 2011), differences at educational levels present higher variation between Mexican origin persons born in the United States compared with those born in Mexico, but who immigrated to this country. The foregoing may be due -among other things- to a higher time exposition to the new society that the second and more generations of immigrants have regarding the first generation (in addition to many adolescents who immigrate looking for labor opportunities, main reason of Mexican migratory flow to the United States).

At the same time, there are other elements that have not been explored by Mexican origin generations, and that have to do with reasons young people dropped out school and that could be related to events marking transition to adulthood. These matters have been more studied in White non-Hispanic and African Americans, observing that educational goals and achievements of youths have a very near relation to transition to adulthood (Hogan and Astone, 1981; 1986; Arnett, 2001).

The objective of this article is to analyze factors and reasons influencing Mexican origin and White non-Hispanic youths dropped out their high school studies. This paper is divided into three sections. First, we present data and methods of the study. Later, a brief synthesis of more relevant findings is presented, concerning factors that have been 
pointed out as influencing Mexican origin and White non-Hispanic youths dropout. Finally, we analyze the influence of various individual, family and contextual characteristics on the high school dropout and we describe the reasons teenagers dropped out school and their bond with transition to an early adulthood.

\section{Data and method}

We used in this article the National Education Longitudinal Survey 1988 - 1992 (NELS: 88-92), in which a cohort of students follow up at American schools is carried out. This source of longitudinal data allows seeing students' conditions when entering high school and to link their starting situation to dropout probabilities. Moreover, it has the advantage of having the information both those who finished high school and those who did not.

NELS: 88-92 is representative at a national level in the United States. It is made up by a cohort of students who were in 8th grade in $1988^{1}$, and who were followed up during this time through interviews effectuated in 1990, 1992, 1994 and 2000. Interviews were carried out to students, professors and students' parents. The survey was divided in three parts: one covers 1988-1992 period; the other, from 1988 to 1994 period and the third one, 1988-2000. In periods after 1992, new cases were incorporated so as to keep representativeness of the sample due to cases lost over the time. Although this situation is statistically resolved for those who are incorporated because they are questioned about their situation in 1988, the inconvenience of using periods after 1992 is that follow up is not possible for students who started in 1988. In this paper, we use NELS: 88-92, since we have all the information of this period of all the students who started eighth grade. Additionally, cross-sectional analysis about their high school termination in $1992^{2}$.

Population of interest of this paper is Mexican origin and White non-Hispanic youths. These last ones are all those declared as White non-Hispanic born in the United States. Mexican origin teenagers group was featured by three generations. The first generation considered all those born in Mexico and who immigrated to the United States. The second generation included all those born in United States but at least one of their parents (mother, father or both) born in Mexico. Third generation considered all those both parents and children born in United States, but declared their Mexican origin.

Multi-varied and descriptive methods were used for data analysis. In the first case, two binomial logistic models were adjusted for determining influence of individual, familial and contextual characteristics about high school dropout from Mexican origin and White non-Hispanic youths. In these type of models we used a dichotomous or dummy variable as dependent variable. The general formula for logistic regression is (Agresti, 1996; Pampel, 2000):

$$
p=\frac{e^{z}}{1+e^{z}} \text { or } \quad p=\frac{1}{1+e^{-z}}
$$

Where $\mathrm{Z}$ is:

$$
Z=\beta_{1} X_{1}+\ldots+\beta_{p} X_{p}+\beta_{0}
$$

and $\beta_{0}, \beta_{1}, \ldots \beta_{p}$ are unknown parameters to estimate:

$$
p_{i}=\frac{1}{1+e^{-\left(\beta_{1} x_{i 1}+\ldots+\beta_{p} x_{i p}+\beta_{00}\right)}}
$$

The interpretation of logistic regressions are based on odds ratio. The mean of a dummy variable equals the proportion of cases with a value of 1 , and can be interpreted as a probability (Pampel, 2000: 1):

$$
\frac{p}{1-p}=e^{\beta o} * e^{\beta_{1} X_{1}} * e^{\beta_{2} X_{2}} * \ldots * e^{\beta_{n} X_{n}}
$$

\footnotetext{
${ }^{1}$ Eight grade precedes high school studies. In Mexico, this grade is equivalent to secondary school second year.

2 This period analysis coincides with one of the changes observed in migratory patterns of Mexico toward the United States, meaning, when immigration became more permanent and less temporary, which has implicated the movement not only of immigrant but his family as well. Such change may bring with it the incorporation of immigrants and his children to educational system in the United States. When arriving complete families and establishing in the United States, they have to incorporate their children in the schools of this country, which is important to stand out because in the past, it was observed a familial immigration in lesser extent, and when it occurred in this way, generally all the members of the home were incorporated to labor market (Massey, 2003; Gammage \& Schmitt, 2004; Durand, 2006; Delgado \& Marquez, 2007).
} 
After logistic model, we present a description about reasons for dropping high school. In this case, and because variables used make reference to open questions ${ }^{3}$, it was decided to divide by groups and answers description offered by young people about reasons to drop out school.

\section{Background}

Different researches establish that one of teenagers educational level determinants is family socioeconomic status, which determines the kind of neighborhood in which they live, and the quality of school their children attend and the group of person with whom they are related (Portes \& Zhou, 1993; Zhou, 1997; Portes, 2008). At the same time, some studies propose familial composition influences children education, emphasizing that the presence of the two parents provokes and encourages high, strong educational achievements and ambitions from the children (Fitzpatrick \& Yoels,1992; Nan \& McLanahan, 1994; Bogges, 1998; Schmid, 2001; Rumbaut \& Portes, 2001; Mier y Terán \& Rabell, 2004). Likewise, parents' education, their labor situation and social origin are factors influencing children education (Coleman \& Husen, 1989; Schmid, 2001; Feliciano, 2005).

School context has been stated as an element that may influence educational level of teenagers, standing out the kind of school they are, where it is located, as well as racial groups going to educational institutions (Murnane, 1984; Evans \& Schwab, 1995; Smith \& Meierr, 1995; Hofferth, Boisjoly \& Duncan, 1998; Lee \& Burkam, 1998; Sander, 1999; Kirkpatrick \& Crosnoe, 2001; McLanahan, Haskins \& Donahue, 2005; Gilbert, 2008).

It is important to mention that most of the studies looking for explaining influence of different aspects about young persons' education are not referred in all Mexican cases, but they are a necessary precedent to be approached to explain the role of different characteristics of students about their educational achievements. Next, we synthesized some of the main findings related to characteristics influencing youth education.

\subsection{Individual Characteristics}

Concerning young people individual characteristics, some studies have showed there are educational differences between Mexican origin and White non-Hispanic adolescents (Román, 2010). Regarding this, explanations may be varied. For example, it has been established that Latin immigrants in United States have low educational achievements compared with those born in that country, but much of this is attributed to low educational levels obtained in the country of origin of immigrants. Nonetheless, even though reduced levels of human capital and poor previous academic achievements, it has been observed immigrants that arrived to United States during their childhood and before school age, obtain educational status similar to those of second generation (Alba and Nee, 1997; White \& Glick, 2000; Waters, et al., 2010). In the same way, although it does not offer an explanation about its occurrence, it has been observed that recent Mexican immigrants who have stayed from one to five years in the United Stated, have less probabilities of going to college than those who have been more time. In general, it can be said that arriving at an earlier age allows teenagers to be incorporated to school from basic levels of educational system, which, therefore, will permit them a higher approach to educational environment (Alba \& Nee, 1997; Vernez \& Abrahamse, 1996; Portes, 2008).

Similarly, it has been indicated that educational development of immigrant children and youth may depend, among other things, on English learning as a second language (Tinley, 2003). That is, speaking, writing and reading skills may play a central role in the development of human capital of individuals, which will allow them more opportunities to grow professionally, both in the school and the job. According to some studies, English abilities are a necessary tool to finish the school, not only because they can interchange and express their ideas with their classmates and teachers, but also because English language grants them a higher access to schools and nets' support, essential to get school success (Stanton-Salazar \& Dornbusch, 1995; White \& Glick, 2000; Golash, 2005).

In terms of relation between immigrant generations and English language command, it has been seen that although some immigrants learn English, generally they prefer speaking their native language, especially at home, in a way younger people usually grow as bilingual. Nonetheless, there are some studies showing one point five and second generation children prefer speaking English all the time and they do not use their native language (Rumbaut \& Portes, 2001). Other researches specify that second generation speaks English at home (Schmid, 2001; Alba, Logan \& Lutz, 2002); likewise, some studies about third generation assert English is the prevailing language of this group and they speak their parents or grandparents' language in a very fragmented way (Alba, Logan \& Lutz, 2002).

\footnotetext{
3 Generally, in the survey there exist "closed" questions and answers, which refer to questions with answers containing categories previously established by the researcher. It is said that questions and answers are "opened" when a questioning is made, and the interviewed person is allowed to offer his/her opinion without being restricted to specific answers.
} 
On the other hand, some researches state when speaking English at home is more a measure of acculturation than a factor associated with high school graduation, or college continuation (Vernez \& Abrahamse, 1996; McLanahan, Haskins \& Donahue, 2005). Other studies have found a positive relation between bilingualism and cognitive skills (Golash, 2005). It is discussed bilingual children have more cognitive flexibility than children who speak only one language. Additionally, it has been established that being bilingual promotes academic achievements and leads to high academic expectations. With respect to this, it has been proposed is due to the fact bilingual students have more access to community schools and networks (Stanton-Salazar \& Dornbusch, 1995; Mouw \& Xie, 1999; Golash, 2005).

A gender difference is another aspect that has been stated as an element influencing teenagers' educational status. However, there is no point of agreement respecting that. Some researches express women are more likely to drop out school because of familial reasons. On the other hand, have found women tend more to end their studies compared with men (Giorguli, White \& Glick, 2003).

Another cause of school dropout that has been analyzed is students' labor incorporation. It is expected that a student integrated to work market has more difficulties to continue studying. This is due -according to researches- to difficulty to organize study and work time (Foote \& Martin, 1993; McNeal, 1997; Eckstein \& Wolpin, 1999; Entswile \& Alexander, 2004). Particularly, it has been observed there is a strong relation between employment intensity and high school dropout. Students working more than 20 hours a week have more probabilities to drop out school than those working less than 20 hours (McNeal, 1997).

Mexican studies have showed children participate in domestic labors more frequently when there are conditions that hind adults' home tasks, as it happens at homes where mother is part of labor market, or where there is a strong work domestic work, as in large families, or where there are little kids, old people or sick ones requiring special cares, among others (Camarena, 2000). Even though there is not enough evidence about chores and their influence on youth school performance, some researches indicate domestic duties will have the same implications than extra-domestic job on young people school education (Camarena, 2004; Mier y Terán \& Rabell, 2004).

Different studies have stated students having better educational results and showing less behavior and delinquency problems are those more academically committed and those who feel they are part of the school. Among school commitment indicators are established: to work hard in class, to participate in school events, to finish duties, to attend and to stay at classes, and to participate in extra-curricular activities (Steinberg, Brown \& Dornbusch, 1996; Kirkpatrick \& Crosnoe, 2001; McLanahan, Haskins \& Donahue, 2005). Specifically, it has been found that high school students' participation in certain extra-curricular activities (sport and arts activities) is associated with a higher school commitment, meanwhile participation in academic or vocational clubs have no effect. When all activities are examined simultaneously, only the participation in sport activities is positively associated with non-school dropout (McNeal, 1995). Probably, this last one happens since if the student is involved in this kind of activities, he establishes close relations with classmates, which encourage their school continuation.

\subsection{Family Characteristics}

With respect to familial structure, we have different findings, some referred to Mexican cases, and they may not coincide with United States situation. However, such researches allow having a reference regarding that, in addition to the possibility some immigrant patterns and their descendants may be reproduced at hostess society. Mexican studies (Mier y Terán \& Rabell, 2004) find that in nuclear family (father, mother and children), the probability that children are dedicated only to study are very high, which is explained by the more direct flow of resources from parents to children ${ }^{4}$. In the United States there are similar results, stating that nuclear families' children have a high school attendance than those from large families. Also, an important factor from economical and social welfare that has been found is the presence of both parents at home (Rumbaut \& Portes, 2001). Children who were up brought by both parents are more successful at school than those who lived only with one of the parents at any moment of their childhood, since the first ones have higher probabilities of finishing high school and to attend and to graduate from college (Fitzpatrick \& Yoels, 1992; Nan \& McLanahan, 1994). Moreover, it has been observed that children coming from immigrant nuclear families have high school grades' average, low dropout rates and higher ambitions than those in which the presence of one of the parents is missed (Boggess, 1998; Schmid, 2001).

According to some studies, non-nuclear family's young people have more behavioral problems and low results in cognitive tests than young persons who live in homes with both biological parents (Morrison \& Cherlin, 1995; Kao,

\footnotetext{
${ }^{4}$ According to some studies, this is because in the traditional approach of nuclear family, a distinguished work division is proposed between the members of the home, where: the husband is the supplier of economical resources; the wife is in charge of domestic labor, and the siblings have- as main task- to study (Camarena, 2000).
} 
2004; Aughinbaugh \& Rothstein, 2005). It is stated that in monoparental families (father or mother, and children) adolescents have less probabilities to be dedicated only to school in the United States. Hofferth, Boisjoly \& Duncan (1998) point out that children in an only one-parent home tend more to drop out school compared with those who live with both parents. At the same time, a big percentage of school dropouts do not live with their parents and it is more likely to get married at an earlier age than their counterparts (Boggess, 1998; Fry, 2005).

It has been found that children who live with both biological parents or only with their mother have a higher occupational status and education achievements than children who live with a stepfather or only with the father (McLanahan \& Sandefur, 1994; Nan \& McLanahan, 1994; Ginther \& Pollak, 2004; McLanahan, Haskins \& Donahue, 2005). An explanation about these findings may be that biological mothers and fathers invest more on school for their children than the adoptive parents (Biblarz \& Raftery, 1999; Ginther \& Pollak, 2004).

On the other hand, evidences found in Mexico have showed that in large families ${ }^{5}$, in general, there are more resources coming from adults per child than in other type of families, since children number is lower regarding adults. The foregoing situation provokes that, if there is a lack of economic resources, children maintenance cost is shared between more adults, and children or teenagers have more probabilities to be dedicated to study instead of working (Mier y Terán \& Rabell, 2004).

Also, the number of siblings affects education. It has been stood out that likeliness a young person studies is reduced as the number of siblings is increased because it is an indicator that attention to children and their economical welfare is going to be reduced, among other things. It is specially stated that to have more than three siblings is negatively related to be graduated from high school (Vernez \& Abrahamse, 1996; Bianchi \& Robinson, 1998; Hofferth, Boisjoly \& Duncan, 1998; Sander, 1999; McLanahan, Haskins \& Donahue, 2005). The foregoing is associated with what Knodel (1991) calls effects of dissolution, which, as number of siblings increases, available family resources for a child in particular are reduced. "Resources" are understood as the time parents dedicate to their children, as well as material and financial means.

On the other hand, in a study about educational inequality between White and Mexican origin adolescents at the Southwest of the United States, it was found that familial background is the main explanatory factor of educational disadvantage between groups (Gilbert, 2008). Regarding this point, Schmid (2001) points out that children whose parents are more educated, have high labor status and higher incomes and tend to reach high educational levels. Other researches find that high education parents' children study and read more and watch less TV than their counterparts (Ensminger \& Slusarcick, 1992). At the same time, it has been observed that children of mothers working half time watch significantly less TV than children whose mothers are at home all the time. It seems parents education is an important indicator of the investment of human and social capital their children receive. Mothers who graduate from college, dedicate more time to children care, by teaching them and learning educational novelties compared with mothers with less educational status (Bianchi \& Robinson, 1998). Additionally, it has been found that when mothers have high school studies, the probability their children obtain the same educational level is increased (Sander, 1999; McLanahan, Haskins \& Donahue, 2005). That is, parents with the same high educational status and in a good social position are in conditions of transmit these disadvantages to their children. Maybe, this is due to a higher parents' capacity to encourage their children to study and to make them conscious about advantages that they can get in the future when reaching certain educational level (Coleman \& Husen, 1989; Feliciano, 2005).

In contrast, the slowest students come from families who have no instruction and culture, although they do not necessarily lack for economical means. Generally, low familial incomes and parents with reduced school levels are elements strongly associated with low school performance of the children (Levine, 2001). For example, it has been observed in Mexican young people in United States that parents' low educational levels generate high rates of school dropout and poor academic achievements (Rumbaut \& Portes, 2001).

Generally, reduced parents' participation in the school performance of their children, acts as an element for school dropout, especially among Latin students (Schmid, 2001). There are some ways in which parents can be involved in their children school follow up, either through attendance to school meeting, homework revision or activities promotion developing interest to learn new things. For example, some studies state low incomes families motivate the development of their children by attending school meetings, by helping to do homework and by organizing familial visits to museums, as well as to plan strategies so as to encourage their skills and interests. At the same time, such families are interested in knowing where their children go and to know their friends, since they consider this kind of strategies can prevent them from negative influences (Hofferth, Boisjoly \& Duncan, 1998; Ginther \& Pollak, 2004).

\footnotetext{
${ }^{5}$ Large family includes nuclear families or monoparental with other relatives.
} 


\subsection{Contextual Characteristics}

Some studies suggest that the kind of school influences students' educational achievements. There are people who establish private schools are more effective than public ones in helping students to acquire higher cognitive skills. For example, private schools' students are more advanced in Mathematics courses than public schools' students (Murnane, 1984; Hofferth, Boisjoly \& Duncan, 1998; Lee \& Burkam, 1998; Gilbert, 2008). At the same time, it has been indicated that those who attend private schools tend more to study high school and to enter college than those from public schools. This can be explained because private schools incorporate students who have very low probabilities of academic failures (Evans \& Schwab, 1995; Smith \& Meierr, 1995; Lee \& Burkam, 1998; Sander, 1999).

Private schools can be categorized as catholic and non-Catholic ones. It is proposed that non catholic private schools' students show higher curricular advantages in Mathematics than those from public ones (Lee \& Burkam, 1998; Sander, 1999). On the other hand, it has been indicated there is a positive effect to attend catholic private schools on students' educational achievements, especially in big cities where public education quality is poor. Catholic secondary schools are geographically concentrated in urban areas and increase significantly educational achievements between minority groups. Students suggest urban minorities are enormously benefited when entering first in catholic schools because for them, public ones available are very poor. This effect is less clear if catholic private schools are in areas where public educational quality is relatively high (Murnane, 1984; McNeal, 1997; Gilbert, 2008).

Previous indications point out not only that the kind of school influences young people's education, but also the area where schools is located. Concerning this, some researches find school districts of big cities do not have an appropriate infrastructure for non-White non-Hispanic students to learn English language. Moreover, there is a lack of appropriate instruction material and training personnel (Sander, 1999). On the other hand, it has been observed in rural areas that teenagers coursing high school are less prone to enter college than those who go to non-contextual rural schools, even though it is not indicated if this is a consequence of students' performance or of any other factor, like higher institution resources (Vernez \& Abrahamse, 1996).

Another relevant aspect associated with school context is the one dealt with racial adolescents'groups coexistence in the classroom. According to some authors, the insertion of students to schools, where they coexist with similar racial groups, it is an indicator of educational and socio-economical segregation. The foregoing is derived as a consequence Hispanic and Black children attend low White percentages' schools, which generally are located in poor stratum, and White adolescents go to institutions with higher resources and with high White non-Hispanic high percentages. All of it will limit educational development of young people and will reproduce existing inequality between racial groups (Kirkpatrick \& Crosnoe, 2001; Gilbert, 2008).

In general, it may be said that summarized researches show there is a diversity of factors that may influence students' educational achievements. In the case of Mexicans, these same aspects could explain elements that determine their continuity in high school.

\section{Results}

\subsection{Influencing Factors in High School Dropout of Mexican Origin and White Non-Hispanic Youths}

From summarized researches, a series of individual, familial and contextual variables to observe influence on them about not ending high school from Mexican and White non-Hispanic young people. For that we use a binomial logistic regression model. In these types of models the dependent variable is dichotomous and independent variables could be categorical or non-categorical. In this case the dependent variable is high school dropout $(0=$ do not dropout high school; $1=$ dropout high school). The independent variables used are categorical: generation, age, English language, hours dedicated to work, chores, attend classes, sports activities, socioeconomic status, family structure, siblings, parents' education, language at home, parents' attendance to school meetings, type of school, localization of school and percentage of Hispanics in classrooms.

Contrary to what has been proposed in diverse studies (Vernez \& Abrahamse, 1996; Alba \& Nee, 1997), in which the first generation used to have higher educational disadvantages compared with other generations, the results of the binomial logistic regression model shows that there are no statistically significant differences between generations of Mexican students. This indicates that generation is not an element influencing school dropout (table 1).

On the other hand, it is found to be man or woman is not statistically significant; this means, gender is not determinant when high school studies are not concluded (table 1). This is an interesting result because different researches assert that gender is an important variable to continue studying high school (Giorguli, White \& Glick, 2003), situation not happening to Mexican origin and White non-Hispanic youths. 
For Mexican and White non-Hispanic people, age they had in eighth grade ${ }^{6}$ is one of the variables influencing more to not end high school studies. It is important to indicate that being 16 years old or more increases significantly the probabilities of leaving high school compared with young people under that age. Although in researches about factors affecting adolescents' educational status, age is not an aspect stated as influent on school dropout. Our results show that to study lately eighth grade is an important predictor that teenagers will not conclude high school (table 1).

Different researches have indicated English language ability ${ }^{7}$ is a factor affecting school continuity of young immigrants (Stanton-Salazar \& Dornbusch, 1995; White \& Glick, 2000; Tinley, 2003; Golash, 2005). In this case, we observed limitations on school performance due to English language are not a statistically significant variable for dropout of Mexican origin youths (table 1).

Concerning hours dedicated to work, it can be observed that both Mexican and White non-Hispanic youths working more than 20 hours per week have higher risk of not being graduated, in contrast to those who do not work. On the other side, for Mexican also, to work 20 hours per week increases the risks of leaving their studies (table 1).

On the other hand, contrary to what could be expected, the fact White non-Hispanic young people do their domestic tasks not so frequently (rarely/never) increases the risks of not being graduated on time from high school, compared with those who do this kind of jobs frequently. It is important to mention this variable does not influence Mexican origin adolescents (table 1). It may be said chores do not have the same impact on extra-domestic activities, as it has been indicated in some researches (Camarena, 2004; Mier y Terán \& Rabell, 2004).

Mexican and White non-Hispanic adolescents who do not attend classes more than one day per week have higher probabilities of not concluding their high school studies, compared with those who always attend their classes. Likewise, those who do not practice sport activities at school have more pointless reasons for not being graduated from high school unlike those who do sports (table 2). This behavior confirms what is proposed in other studies that assert young people who practice sports have a higher school commitment (McNeal, 1995).

Socioeconomic status has been established as a determinant element for continuing school, being indicated that Mexican origin young people from low stratum will have less possibilities of concluding their studies compared with those from more favored strata (Zhou, 1997; Levine, 2001). In this case, we observe such behavior is reproduced for Mexican and White non-Hispanic adolescents, since in both cases, those who belong to the lowest stratum have more pointless reasons for not concluding their high school studies than those who belong to middle-high strata (table 1).

The role of familial structure is determinative for White non-Hispanic youths, since students not residing with both parents show more pointless reasons for not ending high school, being higher for those who only with the father or other relatives. On the other hand, it is surprising that Mexican young people living with their mother are the only ones having higher risks of dropping out school, and that such situation does not occur in other kind of familial structure (table 1). This last position cannot be an indicator that youth will be part of work market at an earlier age in order to contribute with familial economy.

Similarly, and according to what was observed in other studies (Vernez \& Abrahamse, 1996; Bianchi \& Robinson, 1997; Hofferth, Boisjoly \& Duncan, 1998; Sander, 1999), here, it can be seen that for both Mexican and White non-Hispanic ones, to have more than three siblings increases the probabilities of not being graduated from high school, in contrast to those who have a more reduced number of siblings.

Another result obtained from Mexican and White non-Hispanic adolescents is concerning parents' formal education, since in this case, the fact youth parents have studies lower than high school, increases the pointless reasons of their children for not finishing their studies, in opposition to those parents having higher studies than high school. This behavior - in less extent - is also presented in students whose parents' studies level is high school (table 1).

Regarding language spoken at home, diverse studies have indicated that some Mexican generations speak English all the time, and they do not use their native language (Rumbaut \& Portes, 2001; Schmid, 2001; Alba, Logan \& Lutz, 2002), even though it is not indicated if this is a factor affecting her educational achievements. In this case, it is observed there are no statistically significant differences between teenagers speaking at home a different language than English than those who speak English at home, so it is not an element determining high school conclusion (table 1).

On the other hand, an aspect not very explored in researches, but showing here to be an influence on White non-Hispanic adolescents educational stage (not occurring in Mexicans), is the one associated with parents involved in

\footnotetext{
6 Eighth grade is the year in which students' cohort follow up started. This grade precedes high school entrance.

7 This variable was created by a question about students' school performance related to English language applied to teachers.
} 
their children school activities, specially the one concerning parents' attendance to school meeting, being observed that if parents do not attend meetings, students show higher risks of leaving high school (table 1).

When factors related to school context into models are incorporated into public schools attended by Mexican and White non-Hispanic young people, pointless reasons for not ending their studies are increased in regards to those who go to private, religious or not religious institutions. It is very probable this result is associated with poor educational quality of some public schools that generally affect school dropout (Gilbert, 2008). At the same time, those who attend rural schools have less risks of not ending high school, in contrast to those in urban area schools. This last is important, since unlike what is known in Mexico, American rural schools are not necessarily of poor quality and hard access (table 1).

Hispanics' percentage in classrooms between Mexican teenagers only increases the risk of leaving the school when attending a classroom from a rank from 21 to 50 percent compared with those who have low percentages of Hispanics in their classrooms (up to 10 percent). Nonetheless, to White non-Hispanics, any percentage of Hispanics in classroom higher than 10 percent increases the probabilities of not ending high school. This last result supports proposals about educational segregation which is faced by Hispanics, being indicated they are generally inserted in schools with poor educational quality and other deprivations, which limit students' educational achievements in such institutions, in this case, those of White non-Hispanics (Gilbert, 2008).

Table 1. Binomial Logistic Regressions for High School Dropout from Mexican Origin and White non-Hispanic Youths in United States, 1988- 1992

\begin{tabular}{|c|c|c|c|c|}
\hline \multirow[b]{2}{*}{ Generation } & \multicolumn{2}{|c|}{$\begin{array}{c}\text { Mexican origin } \\
\operatorname{Exp}(\mathbf{B})\end{array}$} & \multicolumn{2}{|c|}{$\begin{array}{c}\text { White non-Hispanic } \\
\operatorname{Exp}(\mathbf{B})\end{array}$} \\
\hline & & & & \\
\hline 1st generation & 0.767 & & & \\
\hline 2nd generation & 0.802 & & & \\
\hline 3rd generation & 1.000 & & & \\
\hline \multicolumn{5}{|l|}{ Gender } \\
\hline Man & 0.858 & & 1.097 & \\
\hline Woman & 1.000 & & 1.000 & \\
\hline \multicolumn{5}{|l|}{ Age } \\
\hline 15 years old & 2.050 & * & 1.726 & $*$ \\
\hline 16 years old or more & 4.809 & * & 6.580 & * \\
\hline 14 years old & 1.000 & & 1.000 & \\
\hline \multicolumn{5}{|c|}{ Limitations on school performance due to English language } \\
\hline Limited & 0.846 & & & \\
\hline No limited & 1.000 & & & \\
\hline \multicolumn{5}{|l|}{ Hours dedicated to work } \\
\hline More than 20 hours & 2.095 & $* *$ & 1.446 & $*$ \\
\hline 20 hours or less & 1.592 & * & 0.992 & \\
\hline Do not work & 1.000 & & 1.000 & \\
\hline \multicolumn{5}{|l|}{ Domestic tasks (chores) } \\
\hline Rarely/never & 1.318 & & 1.215 & $* * *$ \\
\hline Frequently & 1.000 & & 1.000 & \\
\hline \multicolumn{5}{|l|}{ Do not attend clases } \\
\hline More than day per week & 2.426 & * & 2.472 & $*$ \\
\hline Always attend clases & 1.000 & & 1.000 & \\
\hline \multicolumn{5}{|l|}{ Sports activities in school } \\
\hline Do not practice sports in school & 1.498 & $* *$ & 1.455 & $*$ \\
\hline Practice sports in school & 1.000 & & 1.000 & \\
\hline \multicolumn{5}{|l|}{ Socioeconomic status } \\
\hline Low & 2.844 & * & 1.885 & $*$ \\
\hline Middle-High & 1.000 & & 1.000 & \\
\hline \multicolumn{5}{|l|}{ Family structure } \\
\hline Mother and stepfather & 1.509 & & 1.683 & $*$ \\
\hline Only mother & 1.638 & $* *$ & 1.585 & $*$ \\
\hline Father and other relatives & 1.471 & & 2.375 & $*$ \\
\hline Mother and father & 1.000 & & 1.000 & \\
\hline
\end{tabular}




\begin{tabular}{|c|c|c|c|c|}
\hline \multicolumn{5}{|l|}{ Number of siblings } \\
\hline 3 or more siblings & 1.377 & $* * *$ & 1.265 & $*$ \\
\hline Less of 3 siblings & 1.000 & & 1.000 & \\
\hline \multicolumn{5}{|l|}{ Parents' education } \\
\hline High school graduated & 1.636 & $* *$ & 1.812 & $*$ \\
\hline Less of high school & 2.113 & $*$ & 3.074 & $*$ \\
\hline More than high school & 1.000 & & 1.000 & \\
\hline \multicolumn{5}{|l|}{ Language spoken at home } \\
\hline Spanish & 0.924 & & & \\
\hline Other & 2.354 & & & \\
\hline English & 1.000 & & & \\
\hline \multicolumn{5}{|l|}{ Parents' attendance to school meeting } \\
\hline Do not attend meetings & 1.047 & & 1.313 & $*$ \\
\hline Attend meetings & 1.000 & & 1.000 & \\
\hline \multicolumn{5}{|l|}{ School } \\
\hline Public & 2.516 & $* * *$ & 1.376 & $*$ \\
\hline Private (religious or not religious) & 1.000 & & 1.000 & \\
\hline \multicolumn{5}{|l|}{ School's localization } \\
\hline Rural & 0.684 & $* * *$ & 0.840 & $* * *$ \\
\hline Suburban & 0.834 & & 1.055 & \\
\hline Urban & 1.000 & & 1.000 & \\
\hline \multicolumn{5}{|l|}{ Hispanics' percentage in classrooms } \\
\hline 11 to $20 \%$ & 1.060 & & 1.394 & $* *$ \\
\hline 21 to $50 \%$ & 1.791 & $* *$ & 1.661 & $*$ \\
\hline More than $51 \%$ & 1.122 & & 1.960 & $* *$ \\
\hline $10 \%$ or less & 1.000 & & 1.000 & \\
\hline
\end{tabular}

Source: own calculations from NELS: 88-92.

\subsection{Reasons Behind of High School Dropout}

Influence of individual, familial and contextual factors about Mexican origin and White non-Hispanic youths school dropout allow knowing the probabilities adolescents have to drop out high school according to their characteristics. However, the reasons the students quit school are invisible in the factors' analysis. This is relevant since those motivations could be events marking the transition to youth earlier adulthood. Moreover, it is important to consider that in the United States, like in other countries, transition to adult life is different between social and ethnic groups. Some of these differences are due to factors of selection, for example, insufficient resources may limit the entrance of youth to college or to the university, once they are graduated from high school, or racial discrimination can make hard the incorporation of young people to work market after ending school (Hogan \& Astone, 1981; Arnett, 2011).

It should be noted that social transitions associated with transition to adulthood from youths are related to school ending, work force entrance, marriage, leaving parents' home and to come from sole parent family (Hogan \& Astone, 1986; Echarri \& Pérez, 2007). Generally, the occurrence of these events is visualized in sequence: school dropout, first employment, marriage or cohabitation and first child birth (Echarri \& Pérez, 2007). Such events not always show a consecutive behavior and time. For example, school dropout may occur before concluding studies and may be related to work market entrance, marriage, cohabitation or child birth. Another aspect that has been discussed is the effect of early familial formation (either becoming parents or getting married) over educational achievements. It has been found that women forming a family, either by being married or by being pregnant, during high school studies, have a high risk of leaving school. In the same way, both married men and women tend to drop out school in a higher extent (Nan \& McLanahan, 1994; Fry, 2005).

School dropout reasons of Mexican and White non-Hispanic generations include more than one reason, which is not surprising, since generally one reason is linked to the other one. It is possible that first child birth or pregnancy make young people start working; likewise, familial problems could be associated with the participation of youth in economic activities, which may cause problems at school (table 2). 
Table 2. Reasons of Mexican and White Non-Hispanic Youths to Dropout High School, United States, 1988 - 1992

\begin{tabular}{|c|c|c|c|c|c|c|c|c|c|c|c|c|c|c|c|c|c|c|c|}
\hline & & & & & & & & & & & & & $\mathbf{w}$ & FCH & FCH & $\mathbf{s}$ & $\mathbf{w}$ & $\mathbf{S}$ & \\
\hline & & & & & & $\mathbf{w}$ & $\mathbf{S}$ & $\mathbf{F}$ & $\mathbf{S}$ & FCH & FCH & FCH & $\mathbf{s}$ & $\mathbf{s}$ & $\mathbf{F}$ & $\mathbf{F}$ & $\mathbf{S}$ & $\mathbf{F}$ & TOTAL \\
\hline & $\mathbf{w}$ & $\mathbf{s}$ & $\mathbf{F}$ & FCH & $\mathbf{R M}$ & $\mathbf{S}$ & $\mathbf{R M}$ & $\mathbf{w}$ & $\mathbf{F}$ & $\mathbf{w}$ & $\mathbf{s}$ & $\mathbf{F}$ & $\mathbf{F}$ & w & $\mathbf{w}$ & FCH & RM & FCH & \\
\hline \multicolumn{20}{|l|}{ Mexican origin } \\
\hline 1st generation & 5.0 & 40.0 & 5.0 & 10.0 & 0.0 & 5.0 & 0.0 & 5.0 & 0.0 & 5.0 & 15.0 & 0.0 & 0.0 & 0.0 & 0.0 & 5.0 & 0.0 & 5.0 & 100.0 \\
\hline 2nd generation & 8.7 & 21.7 & 4.3 & 13.0 & 0.0 & 21.7 & 0.0 & 0.0 & 4.3 & 4.3 & 0.0 & 13.0 & 0.0 & 8.7 & 0.0 & 0.0 & 0.0 & 0.0 & 100.0 \\
\hline 3rd generation & 4.5 & 31.8 & 2.3 & 6.8 & 0.0 & 13.6 & 2.3 & 0.0 & 0.0 & 2.3 & 13.6 & 2.3 & 2.3 & 9.1 & 2.3 & 2.3 & 0.0 & 4.5 & 100.0 \\
\hline White non-Hispanic & 4.9 & 46.0 & 0.3 & 3.7 & 0.0 & 21.8 & 0.0 & 0.0 & 1.5 & 1.8 & 5.8 & 1.5 & 2.5 & 2.1 & 1.8 & 2.5 & 1.5 & 2.1 & 100.0 \\
\hline W & \multicolumn{19}{|c|}{ Work force entrance } \\
\hline S & \multicolumn{19}{|c|}{ Problems at school } \\
\hline $\mathrm{F}$ & \multicolumn{19}{|c|}{ Familial problems } \\
\hline $\mathrm{FCH}$ & \multicolumn{19}{|c|}{ First child birth or pregnancy } \\
\hline $\mathrm{RM}$ & \multicolumn{19}{|c|}{ Residential mobility } \\
\hline
\end{tabular}

Source: own calculations from NELS: 88-92.

When main reasons to Mexican origin and White non-Hispanic youths drop out school are considered, it can be seen (graph 1) that problems at school, first child birth or pregnancy and work market entrance, as well as a combination of them are the main reasons for dropping out school. There are some differences between Mexican origin generations, for example, one of the main causes of high school dropout for the first and third Mexican origin generations, as well as for White non-Hispanics is to have problems at school. For the second generation, problems at school and work market entrance are the main reasons to drop out high school. Additionally, around 20 percent of them leave their studies because they become parents and have familial problems.

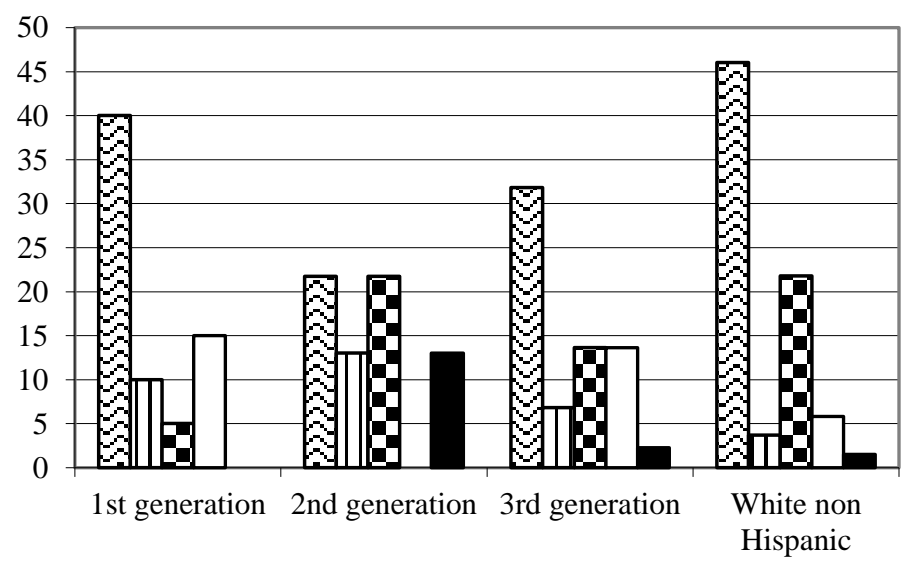

曰School

口First child born or pregnancy

凹Work and school

$\square$ First child born or pregnancy and school

First child born or pregnancy and family

Graph 1. Reasons of Mexican and White Non-Hispanic Young People to Dropout High School, United States, 1988

Source: own calculations from NELS: 88-92. $-1992$

By grouping the reasons in the three categories: first child birth or pregnancy, school problems and work market entrance, it can be observed (graph 2) that for both first generation Mexican and White non-Hispanic youths, school problems are the main reason for dropping out. For Mexican origin second and third generations, first child birth or pregnancy is the main reason for leaving studies. At the same time, work market entrance is very important for the Mexican origin and White non-Hispanic youths second generation 


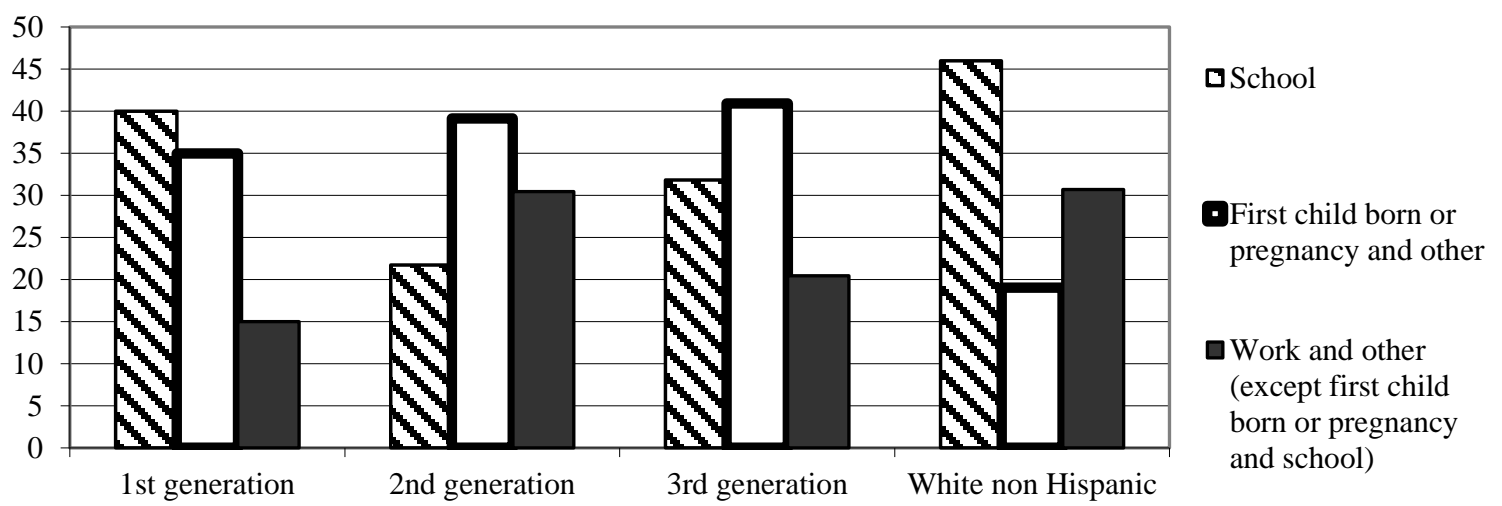

Graph 2. Main Reasons of Mexican and White Non-Hispanic Young People to Dropout High School, United States,

Source: own calculations from NELS: 88-92.

$1988-1992$

\section{Conclusion}

The aim of this article was to determine the influence of different factors, as well as the reasons of Mexican and White non-Hispanic youths for not concluding high school stage. By multi-varied analysis was possible to evidence that individual characteristics of young people have an important influence on concluding their studies. On the other part, familial factors that most affect Mexican and White non-Hispanic adolescents' education are associated with socioeconomic status, familial structure, number of siblings and parents' education. From contextual variables, type of school and area where it is located showed they influence Mexican and White non-Hispanic youth school dropout. It is important to mention that for Mexican origin adolescents, generation and English language do not affect high school dropout.

In particular, it may be said participant factors in dropping out school for Mexican and White non-Hispanic young people are: age, work hours per week, absenteeism, practice of sport activities at school, socio-economical stratum, familial structure, number of siblings, parents' education, kind of school, kind of place where the school is located, and percentage of Hispanics in classroom. All these elements affect similarly to Mexican and a White non-Hispanic educational achievements. It is important to mention that aspects like carrying out domestic duties and parents' attendance to school meetings only showed to affect the continuity of studies of White non-Hispanic young persons, but not of Mexicans. On the other side, contrary to what could be expected, variables considered for Mexican youth, such as generation, limitations to their school performance because of English and language spoken at home, do not explain Mexicans high school dropout.

Another interesting aspect was to go beyond determinants in school dropout when analyzing the main reasons causing youth quit its studies. The fact of dropping out school is itself an element that sets the limits between the different stages of life which youth have to face. In addition to this, there exist elements, like first child birth or pregnancy as determinant so the young people enter early to adulthood. From the results showed, it has been possible to be approached to differences during the transition to adulthood that happen between Mexicans and White non-Hispanics. One of the most important findings is to observe that Mexican origin adolescents, compared with White non-Hispanics present a quicker transition to adult life not only by school dropout, but because main reasons behind such dropout are to become parents and to be incorporated in work market.

\section{References}

Agresti, A. (1996). An Introduction to Categorical Data Analysis. United States: Wiley Series in Probability and Statistics.

Alba, R., \& Nee, V. (1997). Rethinking Assimilation Theory for a New Era of Immigration, International Migration Review, 31(4), 826-874.

Alba, R., Logan, J., \& Lutz, A. (2002). Only English by the third generation? Loss and preservation of the mother tongue among the grand children of contemporary immigrants, Demography, 39(3), 467-484

Arnet, J. (2011). Conceptions of the transitions to adulthood: perspectives from adolescence through midlife, Journal of Adult Development, 8(2), 133- 143. 
Aughinbaugh, P. C., \& Rothstein, D. (2005). The impact of family structure transitions on youth achievement: evidence from the children of the NLSY79, Demography, 42(3), 447-468.

Bianchi, S., \& Robinson, J. (1997). What did you do today? Children's use of time, family composition, and the acquisition of social capital, Journal of Marriage and the Family, 59(2), 332-344.

Biblarz, T. J., \& Raftery, A. (1999). Family Structure, Educational Attainment, and Socioeconomic Success: Rethinking the Pathology of Matriarchy, American Journal of Sociology, 105(2), 321-363.

Bogges, S. (1998). Family Structure, Economic Status, and Educational Attainment, Journal of Population Economics, 11(2), $205-222$.

Camarena, R. M. (2000). Familia y educación en México. In CONAPO, La población de México, situación actual y desafios futuros. México: CONAPO.

Coleman, J., \& Husen, T. (1989). Inserción de los jóvenes en una sociedad en cambio. Madrid: Narcea.

Echarri, C., \& Pérez, J. (2007). En tránsito hacia la adultez: eventos en el curso de vida de los jóvenes en México, Estudios Demográficos y Urbanos, 22(1), 43-77.

Eckstein, Z., \& Wolpin, K. (1999). Why Youths Drop Out of High School: The Impact of Preferences, Opportunities, and Abilities, Econometrica, 67(6), 1295-1339.

Ensminger, M., \& Slusarcick, A. (1992). Paths to High School Graduation or Dropout: A Longitudinal Study of a First-Grade Cohort, Sociology of Education, 65(2), 95-113.

Entwisle, D., \& Alexander, C. (2004). Temporary as compared to permanent high school dropout, Social Forces, 82(3), 1181-1205.

Evans, W., \& Schwab, R. (1995). Finishing high school and starting college: do catholic schools make a difference?, The Quarterly Journal of Economics, 110(4), 941- 974.

Feliciano, C. (2005). Does selective migration matter? Explaining ethnic disparities in educational attainment among immigrants' children, International Migration Review, 39(4), 841- 871.

Fitzpatrick, K., \& Yoels, W. (1992). Policy, School Structure, and Sociodemographic Effects on Statewide High School Dropout Rates, Sociology of Education, 65(1), 76-93.

Foote, K., \& Martin, L. (1993). Family and Development. Summary of an expert meeting. Washington, D. C : National Academy, Press.

Fry, R. (2005). The higher dropout rate of foreign - born teens: the role of schooling abroad. United States: Pew Hispanic Center.

Gilbert, G. (2008). Rich and Poor in America: A Reference Handbook. United States: ABC-CLIO.

Ginther, D., \& Pollak, R. (2004). Family structure and children's educational outcomes: blended families, stylized facts, and descriptive regressions, Demography, 41(4), 671-696.

Giorguli, S., White, M., \& Glick, J. (2003). Between family, job responsibilities and school. Generation, status, ethnicity and differences in the routes out of school, paper presented in Population Association of America, Atlanta.

Golash, T. (2005). Assessing the Advantages of Bilingualism for the Children of Immigrants, International Migration Review, 39(3), 721-753.

Hofferth, S., Boisjoly, J., \& Duncan, G. (1998). Parental extra familial resources and children's school attainment, Sociology of education, 71(3), 246-268.

Hogan, D., \& Aston, N. (1981). Transitions and Social Change: The Early Lives of American Men. New York: Academic.

Hogan, D., \& Aston, N. (1986). The Transition to Adulthood, Annual Review of Sociology. Annual Reviews.

Kirkpatrick, M., \& Crosnoe, R. 2001. Students' attachment and academic engagement: the role of race and ethnicity. Sociology of Education, 74.

Lee, V. and Burkam, D. (1998). Sector Differences in High School Course Taking: A Private School or Catholic School Effect?, Sociology of Education, 71(4).

Levine, E. (2001). Los nuevos pobres de Estados Unidos: los hispanos. México: Miguel Ángel Porrúa.

McLanahan, S., \& Sandefur, G. (1994). Growing Up With a Single Parent: What Hurts, What helps. Cambridge, MA: Harvard University Press. 
McLanahan, S., Haskins, R., \& Donahue, E. (2005). The future of children: marriage and child well-being, Princeton Brookings, 15(2), fall 2005.

McNeal, R. Jr. (1997). Are students being pulled out of high school? The effect of adolescent employment on dropping out, Sociology of Education, 70(3), 206-220.

McNeal, R. Jr. (1995). Extracurricular Activities and High School Dropouts, Sociology of Education, 68(1), 62-81.

Mier y Terán, M., \& Rabell, C. (2004). Familia y quehaceres entre los jóvenes. In M. Ariza, \& O. de Oliveira(eds.), Imágenes de la familia en el cambio de siglo). México: Instituto de Investigaciones Sociales de la Universidad Autónoma de México (IISUNAM).

Morrison, R., \& Cherlin, A.J. (1995). The Divorce Process and Young Children's Wellbeing: A Prospective Analysis, Journal of Marriage and the Family, 57(3), 800-812.

Mouw, T., \& Xie, Y. (1999). Bilingualism and the Academic Achievement of First and Second- Generation Asian Americans: Accommodation with or without Assimilation? American Sociological Review, 64, 232-252.

Murnane, R. (1984). A review essay-comparisons of public and private schools: lessons from the uproar, The Journal of Human Resources, 19(2), 263-277.

Nan, M., \& McLanahan, S. (1994). Family Structure, Residential Mobility, and School dropout: A research Note, Demography, 31(4), 575-584.

Neidert, L., \& Farley, R. (1985). Assimilation in the United States: an analysis of ethnic and generation differences in status and achievement, American Sociological Review, 50(6), 840-850.

Pampel, F. (2000). Logistic regression. Iowa City: Sage Publications.

Portes, A., \& Zhou, M. (1993). The New Second Generation: Segmented Assimilation and its variants, Annals of the American Academy of Political and Social Science, 530, 74-96.

Portes, A. (2008). Migration and Social Change: Some conceptual reflections. Princeton University.

Román, A. (2010). Educación y asimilación socioeconómica de los jóvenes de origen mexicano en Estados Unidos. Ph. D. dissertation, El Colegio de México.

Rumbaut, R., \& Portes, A. (2001). Ethnicities, children of immigrants in America. USA: University of California.

Sander, W. (1999). Private schools and public school achievement, The Journal of Human Resources, 34(4), 697-709.

Schmid, L. C. (2001). Educational achievement, language - minority students, and the new second generation, Sociology of Education, 74 (extra issue), 71-87.

Smith, K., \& Meierr, K. (1995). Public choice in education: markets and the demand for quality education, Political Research Quarterly, 48(3), 461-478.

Stanton-Salazar, R. D., \& Dornbusch, S. M. (1995). Social Capital and the Reproduction of Inequality: Information Networks among Mexican-Origin High School Students, Sociology of Education, 68(2), 116-135.

Steinberg, L. D., Brown, B., \& Dornbusch, S. M. (1996). Beyond the Classroom: Why School Reform Has Failed and What Parents Need to Do. New York: Simon, \& Schuster.

Telles, E., \& Ortiz, V. (2011). Generaciones excluidas: mexicano-estadounidense, asimilación y raza. Madrid: Centro de Investigaciones Sociológicas.

Tinley, A. (2003). Migración de Guanajuato a Alabama: Experiencias escolares de cuatro familias mexicanas. Paper presented in Primer Coloquio Internacional sobre migración y Desarrollo. Zacatecas, México.

Vernez, G., \& Abrahamse, A. (1996). How immigrants fare in U.S. education. USA: RAND.

Waters, M., Tran, V., Kasinitz, P., \& Mollenkopf, J. (2010). Segmented assimilation revisited: types of acculturation and socioeconomic mobility in young adulthood, Ethn Racial Stud, 33(7), 1168-1193.

White, M., \& Glick, J. (2000). Generation Status, Social Capital, and the Routes out of High School, Sociological Forum, 15(4), 671-691.

Zhou, M. (1997). Segmented Assimilation: Issues, Controversial, and Recent Research on the New Second Generation, International Migration Review, 31(4), 975-1008.

\section{(cc) $\mathrm{Br}$}

This work is licensed under a Creative Commons Attribution 3.0 License. 